


\section{The Politics of Hate Speech: A Case Comment on Warman v Lemire}

\section{Ranjan K. Agarwal ${ }^{*}$}

In September 2009, the Canadian Human Rights Tribunal waded into a highly public and acrimonious debate about the role of human rights tribunals and commissions, especially in policing hate speech. In Warman $v$ Lemire, ${ }^{1}$ the Tribunal held that section 13(1) of the Canadian Human Rights Act ${ }^{2}$ (CHRA), which prohibits the communication of hate messages, infringed the constitutional guarantee of freedom of expression, section 2(b) of the Charter of Rights and Freedoms. ${ }^{3}$ The decision added to a firestorm of media, political and academic debate about whether anti-discrimination statutes should prohibit hate speech. The Warman decision is complicated by a twenty-year-old Supreme Court ruling, in a 4-3 decision, that a predecessor provision in the CHRA is constitutional. ${ }^{4}$

In this article, I argue that the Tribunal's decision is logically unsound and likely the result of ends-based or teleological reasoning. In my view, ends-based reasoning does not assist in Charter analysis as it produces decisions that call into question the legitimacy of the courts. This article first outlines the facts in Warman and the Tribunal's holding on the constitutional issues. It goes on to survey the legal and constitutional background to the Warman decision and discuss the Taylor precedent. It then describes the Tribunal's reasoning on constitutional issues, including the Taylor decision and amendments to the CHRA after Taylor. Finally, it criticizes the Tribunal's ends-based reasoning and argues that this type of reasoning is illegitimate in constitutional decision-making.

\section{Background}

Richard Warman filed a complaint with the Canadian Human Rights Commission alleging that Marc Lemire communicated hate messages over the Internet in breach of section 13 of the CHRA. Warman is an Ottawa-based lawyer and a former employee of the Commission. He has filed eleven other complaints against individuals and groups he accuses of communicating hate in breach of section 13, all but two of which have resulted in a finding of discrimination by the Canadian Human Rights Tribunal. ${ }^{5}$ Marc Lemire is the former leader of the Heritage Front, a white supremacist organization. ${ }^{6}$

Warman alleged that Lemire is the owner and webmaster of Freedomsite.org, and that comments posted on Freedomsite's message board were hate messages. ${ }^{7}$ At the Tribunal hearing, Warman and the Commission expanded the complaint to allege that: (a) Lemire was also the registered owner of JRBooksonline.com, and hate messages had been posted on JRBooksonline's message board; and (b) Lemire posted hate messages on Stormfront.org's message board. ${ }^{8}$

Lemire admitted to being the webmaster and owner of Freedomsite.org. In 2006, the Tribunal found that Craig Harrison had posted messages to the Freedomsite message board that were in breach of section $13 .{ }^{9}$ A number of other people, including Lemire, posted messages on Freedomsite.org that Warman and the Commission argued were discriminatory. There were also a number of anonymous articles posted on Freedomsite.org. Warman alleged that 
Lemire posted hate messages on Freedomsite. org, that Lemire and Harrison were working in concert in respect of Harrison's postings, and that Lemire incited Harrison and others to discriminate by setting up Freedomsite.org. The Commission supported these arguments and also argued that Lemire was liable in his capacity as website administrator for Freedomsite. org, or vicariously liable for Harrison's conduct. Warman and the Commission made similar allegations about content posted on the JRBooksonline.com website, though Lemire denied being its owner or webmaster, and there was no evidence that Lemire posted messages or content to the website. In respect of Stormfront.org, Warman alleged that Lemire posted a poem on the website that was inflammatory and derogatory towards non-white immigrants, and created a tone of hatred and contempt towards that class of persons. ${ }^{10}$

Lemire defended these allegations on the basis that he was not the owner or webmaster of JRBooksonline.com; that he cannot be liable for other persons' postings on Freedomsite.org; and that his postings on Freedomsite.org and Stormfront.org are not hate messages. Lemire also argued that sections 13,54(1) and 54(1.1) of the $C H R A$ violated his rights under section 2(a), 2(b) and 7 of the Charter and his rights under the Canadian Bill of Rights, ${ }^{11}$ though he did not make any submissions on the latter issue. ${ }^{12}$

On the merits, the Tribunal found that Lemire had breached section 13 of the CHRA with his poem on the Stormfront.org website and the anonymous postings on the Freedomsite.org website, which only he could have posted as he was the website's webmaster. ${ }^{13}$

On the freedom of expression issue, the Commission and the Attorney General of Canada conceded that section 13 of the CHRA breached section 2(b) of the Charter. In considering whether section 13 minimally impaired freedom of expression, the Tribunal held that recent amendments to section 13 removed the "remedial, preventative and conciliatory" nature of the provision..$^{14}$ As such, the Tribunal held that section 13 cannot be justified as a reasonable limit on the section 2(b) right.
The Tribunal dismissed Lemire's section 2(a) claim, saying that there was no evidence that Lemire or anybody else made postings as a matter of conscience or their religious practice. ${ }^{15}$ The Tribunal similarly dismissed Lemire's section 7 claim on the basis that there was no evidence of his life, liberty or security being infringed. ${ }^{16}$

\section{Statutory and constitutional framework $^{17}$}

Section 13 of the CHRA prohibits the communication of messages that are likely to expose a person to hatred or contempt on the basis of a prohibited ground of discrimination, either by telephone or by the Internet:

13. (1) It is a discriminatory practice for a person or a group of persons acting in concert to communicate telephonically or to cause to be so communicated, repeatedly, in whole or in part by means of the facilities of a telecommunication undertaking within the legislative authority of Parliament, any matter that is likely to expose a person or persons to hatred or contempt by reason of the fact that that person or those persons are identifiable on the basis of a prohibited ground of discrimination.

(2) For greater certainty, subsection (1) applies in respect of a matter that is communicated by means of a computer or a group of interconnected or related computers, including the Internet, or any similar means of communication, but does not apply in respect of a matter that is communicated in whole or in part by means of the facilities of a broadcasting undertaking.

(3) For the purposes of this section, no owner or operator of a telecommunication undertaking communicates or causes to be communicated any matter described in subsection (1) by reason only that the facilities of a telecommunication undertaking owned or operated by that person are used by other persons for the transmission of that matter. ${ }^{18}$

Section 13(2) of the CHRA was amended in December 2001 as part of the Anti-terrorism Act. ${ }^{19}$ The new section 13(2) was linked to the "war on terrorism" by the federal government in two 
ways: prohibitions on hate speech would both reduce the risk of terrorism and protect ethnic and religious minorities from persecution in the event of a terrorist attack. ${ }^{20}$

Sections 54(1) and (1.1) provide for remedies for breaches of section 13, including cease-and-desist orders, compensation to the victim up to $\$ 20,000$, and a penalty of not more than $\$ 10,000$. In determining whether to order a penalty, the Tribunal must consider: (a) the nature, circumstances, extent and gravity of the discriminatory practice; and (b) the willfulness or intent of the person who engaged in the discriminatory practice, any prior discriminatory practices that the person has engaged in and the person's ability to pay the penalty. ${ }^{21}$

Section 54(1) was amended in 1998 to expand the order-making power of the Tribunal in section 13 cases. Prior to the 1998 amendments, ${ }^{22}$ the Tribunal was restricted to ordering the respondent to cease and desist his conduct, and awarding the victim up to $\$ 5,000$ in compensation for hurt feelings.

The Charter's section 2(b) guarantees to everyone "freedom of thought, belief, opinion and expression, including freedom of the press and other media of communication." ${ }^{23}$ In Montréal (City) v 2952-1366 Québec Inc, ${ }^{24}$ the Supreme Court of Canada described the legal test for determining whether a law violates section 2(b) as follows:

(a) Does the communication have expressive content, thereby bringing it within section 2(b) protection?

(b) If so, does the method or location of this expression remove that protection?

(c) If the expression is protected by section 2(b), does the impugned law infringe that protection, either in purpose or effect? ${ }^{25}$

Section 2(b) is subject to section 1 of the Charter, which states:

The Canadian Charter of Rights and Freedoms guarantees the rights and freedoms set out in it subject only to such reasonable limits prescribed by law as can be demonstrably justified in a free and democratic society. ${ }^{26}$
In $R v$ Oakes,${ }^{27}$ the Supreme Court established the legal test for determining whether a law that breaches a Charter freedom or right may be limited pursuant to section 1 :

(a) Pressing and substantial objective: the objective of the law must relate to pressing and substantial concerns of sufficient importance to justify limiting a constitutional right or freedom;

(b) Rational connection: the law must be carefully designed to achieve the objective, and not based on any arbitrary, unfair or irrational considerations;

(c) Minimal impairment: the law should impair as little as possible the right or freedom; and

(d) Proportionality: the effect of the law must not be disproportional to the objective. ${ }^{28}$

\section{Canada (Human Rights Commission) $v$ Taylor}

In 1990, the Supreme Court of Canada considered the very issue before the Tribunal in Warman: does the hate message provision of the CHRA violate freedom of expression? In 1979, the Tribunal found that John Ross Taylor and the Western Guard Party breached section 13 of the CHRA by instituting a telephone service whereby any person could dial a telephone number and listen to a pre-recorded message that said Jews were conspiring to control and program Canadian society, including its books, schools and media. ${ }^{29}$

Despite the Tribunal's finding and a ceaseand-desist order, Taylor and the Western Guard Party continued the telephone service. They were subsequently found in contempt; the Western Guard Party paid a fine and Taylor was imprisoned. After Taylor's release, he and the Western Guard Party resumed the telephone service. The Commission sought a contempt order to imprison Taylor. In their defence, Taylor and the Western Guard Party relied on the Charter's freedom of expression provision, which had been proclaimed in the interim. ${ }^{30}$ 
The Federal Court and the Federal Court of Appeal dismissed the application to strike down section 13 of the CHRA as unconstitutional. ${ }^{31}$ At the Supreme Court, the Commission conceded that section 13 breached freedom of expression. The Supreme Court was divided 4-3 on the issue whether section 13 was a reasonable limit on that freedom. ${ }^{32}$

The Court unanimously held that section 13 's objective was "the promotion of equal opportunity unhindered by discriminatory practices." ${ }^{33}$ However, it divided on whether section 13 was rationally connected to that objective. The majority held that section 13(1) "operates to suppress hate propaganda" and reminds $\mathrm{Ca}$ nadians of the "fundamental commitment to equality of opportunity and the eradication of racial and religious intolerance." ${ }^{34}$ The dissenting reasons held that section 13 , especially the words "hatred" and "contempt," were vague and overly broad. ${ }^{35}$ The dissent also took issue with the absence of any defences to a section 13(1) claim. ${ }^{36}$ The majority held that importing a truthfulness defence or a subjective intention requirement would run contrary to the objective of human rights legislation generally. ${ }^{37}$ As a result, the Supreme Court upheld section 13(1), and the cease-and-desist order continued against Taylor and the Western Guard Party.

\section{The tribunal's reasons on the constitutional issues}

As in Taylor, the government in Warman conceded that section 13 breached Lemire's freedom of expression. The issue was whether the infringement could be justified under section 1 .

The Tribunal began by noting that since Taylor was decided, sections 13 and 54(1) had been amended:

Since Taylor, there have been a number of significant changes to s. 13 and its remedial provisions set out in s. 54(1). Under the version of the Act examined by the Taylor decision, the Tribunal could only make an order referred to in s. 53(2)(a) of the Act after finding a s. 13 complaint substantiated. Thus, a person who engaged in this form of discriminatory practice could only be ordered to cease that prac- tice (commonly referred to as a "cease and desist order") and take measures in consultation with the Commission to prevent the same or similar practice from occurring in the future. In 1998 (S.C. 1998, c. 9, s. 28), s. 54(1) was replaced with a provision stating that the Tribunal could not only issue a s. 53(2)(a) order, but it could now also order a respondent

- where the discrimination was willful or reckless, to compensate a victim who was specifically identified in the hate message with special compensation of up to $\$ 20,000$, pursuant to s. 53(3), and

- to pay a penalty of up to $\$ 10,000$.

In addition, s. 13 was amended in 2001 (S.C. 2001, c. 41, s. 88) to insert a paragraph (the current version of s. 13(2)) clarifying that the discriminatory practice set out in s. 13(1) applies to communications by means of a computer or group of interconnected or related computers, including the Internet. ${ }^{38}$

Before embarking on the section 1 analysis, the Tribunal made clear that it was bound by Taylor, and Lemire could only succeed in his challenge if Taylor could be distinguished by reason of these amendments. ${ }^{39}$

In respect of the provision's objective, Lemire argued that the amendments were made as part of the Anti-terrorism Act, and thus demonstrate that section 13(1) is not intended to prohibit discrimination, but instead "is part of the State's strategy to eradicate terrorism, and protect the political, social and economic security of Canada." ${ }^{40}$ The Tribunal dismissed this argument, finding that section 13(1)'s objective remained, notwithstanding the amendments, to protect against discrimination in Canadian society. ${ }^{41}$ Lemire also argued that Taylor was wrongly decided, because the Supreme Court based its finding on section 13(1)'s objective on the Report of the Special Committee on Hate Propaganda in Canada (Cohen Report), which Lemire rebutted using expert evidence. ${ }^{42}$ The Tribunal dismissed this argument as well, finding that Taylor identified section 13(1)'s objective from the whole of the Act, and the expert's criticism of the Cohen Report was not a new fact that justified revisiting this issue from Taylor. ${ }^{43}$ 
On the issue of rational connection, the Tribunal held that section 13(1) remained rationally connected to the provision's objectives, even with the amendments. Lemire had argued that section 13(1) was irrational because it penalized the communication of hate messages over the Internet, but not in any other form (such as if the text was available in a bookstore or library). The Tribunal dismissed this argument, observing that discriminatory texts in a bookstore or library may be subject to provincial human rights statutes and, moreover, the Internet assists in hate messages being "repeatedly" communicated. ${ }^{44}$

In analyzing whether section 13(1) minimally impaired Lemire's freedom of expression, the Tribunal revisited the analysis in Taylor. It concluded that the terms "hatred or contempt" were no more vague or broad than the Supreme Court found in Taylor and there was no basis to displace that finding. ${ }^{45}$

The absence of any requirement that the offender "intended" to communicate the hate messages caused the Tribunal pause in light of the new sanctions in sections 13(1) and 54(1). It noted:

The fact that the cease and desist order was the only available remedy was identified as characteristic of the conciliatory, preventative, and remedial nature of s. 13, upon which the $\mathrm{Su}$ preme Court based its determination that the provision minimally impacted on the freedom of expression. However, the state of affairs in this respect has significantly changed since then, with the inclusion of the penalty provision. The potential "chill" upon free expression may have consequently increased. As a result, the Court's findings regarding whether the absence of an intent condition transgresses the minimal impairment requirement can be revisited. ${ }^{46}$

The Tribunal found the penalty provisions "inherently punitive" and outside the scope of the Tribunal's responsibilities under the CHRA. ${ }^{47}$ The Tribunal was also concerned that Tribunal proceedings are civil in nature, meaning that the burden of proof is lower and there is a lack of institutional safeguards, such as proof of intent and strict application of the rules of evidence as in a criminal proceeding. ${ }^{48}$ The Attorney General argued that the penalty was "administrative" not penal, and intended to ensure compliance with the Act. ${ }^{49}$ The Tribunal dismissed this argument on the basis that a breach of section 54(1) can result (and has resulted) in incarceration for contempt. ${ }^{50}$ Further, the imposition of a penalty under section 54(1) requires consideration of contextual factors, not unlike sentencing in the criminal context, and is not a mathematical administrative calculation. ${ }^{51}$

The final issue that concerned the Tribunal is that Taylor was premised on the Supreme Court's finding the CRHA enforcement of the CHRA was conciliatory and less confrontational that traditional litigation. The experience of section 13(1) runs counter to that view-the Tribunal found that only 4 percent of section 13(1) cases were settled, and in Lemire's case, Warman refused to mediate or conciliate the dispute. ${ }^{52}$

As a result of these distinctions, the Tribunal concluded that section 13(1) did not satisfy the Oakes minimal impairment test. ${ }^{53}$ Given this finding, the Tribunal did not consider the absence of defences to section 13(1) in considering whether the provision was a minimal impairment or the "proportional effects" leg of the Oakes test. ${ }^{54}$ The Tribunal dismissed the complaint against Lemire.

\section{Analyzing the tribunal's decision}

The Tribunal's decision exposes the fault lines in the debate over section 13(1) of the CHRA. The debate has been exacerbated by recent complaints at the Tribunal and in other jurisdictions against Ezra Levant, Mark Steyn and Macleans for inciting hatred against Muslims. These complaints have been sensationalized by the respondents and by the media. ${ }^{55}$ Though the complaints were all dismissed or withdrawn, they resulted in a major review of section 13(1) by the Commission. In my view, the Tribunal's decision reflects a policy view of section 13(1) but not a constitutional view. The logical inconsistencies in the decision suggest that the Tribunal adopted an ends-based approach, which 
risks undermining the legitimacy of the court system.

Judicial decisions are sometimes subject to criticism that they are the product of "endsbased" or teleological reasoning, as compared to "means-based" reasoning. ${ }^{56}$ Ends-based reasoning seems to have been adopted in Canada's Charter jurisprudence as early as 1985 , when the Supreme Court determined that the courts should apply a broad, purposive approach to interpreting rights and freedoms. ${ }^{57}$ The ends-based approach to constitutional decision-making has been criticized in both Canada and the U.S. The main arguments against ends-based reasoning are: (a) principled or means-based decision making serves to justify the judiciary as the final word on the constitutionality of laws; (b) the courts are only legitimate if they employ a reasoned and principled judicial method; and (c) a principled decision will stand the test of time. ${ }^{58}$ In my view, the ends-based approach is too susceptible to politicization and, as a result, can require judges and quasi-judicial decision-makers to be part of the political process. Warman seems to have been decided without sound legal reasoning and, as a result, it brings into question whether the Tribunal was deciding the law as it is, or as it should be based on the current debate. Though the purposive approach does not necessarily lead to ends-based reasons, decision-makers risk logically unsound decisions when they rely too much on "context" in reaching their conclusions. In this case, the Tribunal erred in wrongly applying Taylor and it seems to have done so because of the heated criticism of section 13(1).

The Tribunal's decision fails to distinguish between the constitutionality of section 13(1), which remains unchanged by subsequent amendments to the CHRA, and sections 13(2) and 54, which were added after Taylor was decided. ${ }^{59}$ Taylor upheld section 13(1), and the decision of the Supreme Court of Canada is binding on the Tribunal, so the Tribunal's decision appears wrong on its face. The Tribunal distinguished Taylor by holding that the absence of any penal provisions was "characteristic of the conciliatory, preventative, and remedial nature of s. 13." ${ }^{60}$ According to the Tribunal's reasons, the Supreme Court based its finding that the legislation minimally impaired freedom of expression on this unique characteristic of human rights legislation, which is intended to encourage the parties to acknowledge the principles of equality and non-discrimination.

This reading of Taylor, in my view, is simply incorrect. In Taylor, Chief Justice Dickson, writing for the majority, applied the minimal impairment test by analyzing four arguments for striking down the provision: (1) the phrase "hatred or contempt" is overbroad and excessively vague; (2) the CHRA does not provide for an exemption to protect freedom of expression, like other anti-discrimination statutes do; (3) section 13(1) is overbroad because it lacks an intent requirement or does not provide for the defence of truthful statements; and (4) the restriction on telephonic communications is an intrusion on individuals' privacy rights. The Chief Justice dismissed each of these arguments as insufficient to render section 13(1) disproportional to the Act's objectives. ${ }^{61}$

The only reference to the penalty associated with section 13(1) was Taylor's argument that his one-year sentence was too severe a response to a breach of section 13(1). Chief Justice Dickson dismissed that argument as well, on two grounds. First, the penalty was for a contempt order that flowed from Taylor's failure to obey a cease-and-desist order made under the CHRA. Second, the Chief Justice disagreed that there was a chilling effect on freedom of expression, as imprisonment only flowed from an intentional breach of section 13(1): a contempt order can only be made if the respondent continues to disseminate the hate message in the face of a finding that the message constitutes hate speech. ${ }^{62}$

In my view, a potential fine of $\$ 10,000$ is insufficient to take section 13(1) outside the reasoning in Taylor. First, the fine is relatively insubstantial. In Hill $v$ Church of Scientology of Toronto,${ }^{63}$ the Supreme Court declined to set aside an $\$ 800,000$ damages award in a defamation case. If the Supreme Court was not concerned that such an award would have a chilling effect on free speech, it seems incorrect to conclude that a penalty of $\$ 10,000$ or a maximum award of $\$ 30,000$ would have such an effect. 
Second, the only added penalty is monetarythe threat of imprisonment remains the same as before the 1988 amendments, and flows only from a contempt finding. Finally, the new penalties have to be reviewed in light of the addition of section 13(2), which recognizes the impact of the Internet on the dissemination of information, especially hateful information. It is telling that none of the recent hate speech cases deal with telephonic communications, but rather with Internet postings or print media that is accessible online.

The insufficiency of the Tribunal's reasons in Warman coincides with a very public debate about section 13(1) and similar provisions in other jurisdictions. In light of the logical inconsistencies in the Tribunal's decision, my view is that the Tribunal must have taken into account the debate around section 13 in reaching its decision.

In February 2006 the Western Standard, which was published by Ezra Levant, printed cartoons depicting the Muslim prophet Mohammad. ${ }^{64}$ The Islamic Supreme Council of Canada and the Edmonton Council of Muslim Communities complained to the Alberta $\mathrm{Hu}-$ man Rights and Citizenship Commission that the Western Standard breached the hate speech provisions in Alberta's anti-discrimination law. In December 2007, the Canadian Islamic Congress filed complaints against Macleans and Mark Steyn to the Canadian Human Rights Commission, and in Ontario and British Columbia, alleging that the magazine published Islamophobic articles, including a column by Steyn. ${ }^{65}$

Though these complaints were eventually dismissed, they garnered significant press and prompted political responses. In January 2008, a Liberal Member of Parliament introduced a private member's motion to repeal section 13. ${ }^{66}$ In 2009, the House of Commons Standing Committee on Justice and Human Rights Committee investigated the Canadian Human Rights Commission's mandate, specifically with respect to section $13 .{ }^{67}$

Against this backdrop, the Commission asked Professor Richard Moon to consider "the most appropriate mechanisms to address hate messages and more particularly those on the Internet, with specific emphasis on the role of section 13 of the [CHRA] and the role of the Commission." ${ }^{68} \mathrm{He}$ recommended that section 13 be repealed. Sections 318 and 319 of the Criminal $\operatorname{Code}^{69}$ make it an offence to advocate genocide or to incite hatred against a group or to willfully promote hatred against a group on the basis of colour, race, religion, or ethnic origin. Section 320.1 of the Code allows a judge to order the seizure and deletion of hate propaganda found on the Internet. Professor Moon argued that the Criminal Code provisions are sufficient to enforce the prohibition on hate speech in $\mathrm{Ca}$ nadian law. He states: "Hate speech is a serious matter that should be investigated by the police and prosecuted in the courts and should carry a significant penalty." ${ }^{\prime 0}$

\section{Conclusion: Warman and the risk of ends-based reasoning}

The logical inconsistencies in the Tribunal's decision in Warman can only be explained, in my view, by an ends-based approach to judicial decision-making. By declaring section 13 unconstitutional, the Tribunal has taken the debate over section 13 out of the hands of the media and politicians and thrust it upon the courts, with a focus on what the law should be as opposed to what it is.

This type of reasoning is dangerous. It undermines the legitimacy of the court system and constitutional democracy by suggesting that the constitutionality of legislation depends on the policy or political views of a particular time. The risk for constitutional decision-making more broadly is that it makes the courts and tribunals susceptible to arguments of judicial activism. Though such arguments are usually made by same groups and individuals that might support the Tribunal's decision in Warman, my view is that the courts (and the Constitution) are not served by suggestions that their decisions are made with one eye on public opinion.

Ends-based reasoning is that much more dangerous in the context of debates around freedom of expression. In $R \vee \mathrm{Zundel}$, the Su- 
preme Court held that the purpose of section 2(b) is to promote "truth, political or social participation, and self-fulfillment." ${ }^{11}$ That purpose is contrasted with the promotion of equal opportunity unhindered by discriminatory practices, which underpins section 13 of the CHRA and is a principle embodied in section 15 of the Charter. In balancing these two important constitutional or quasi-constitutional objectives, decision-makers have to be careful not to favour one set of rights over the other. Ends-based reasoning may achieve a particular purpose-in this case, making section 13 inoperative, which seems to be an outcome favored by politicians, the media and some academics-but the decision risks being attacked as illegitimate if the decision-making logic is unsound. The danger in section 2(b) cases is that decisions risk favoring majoritarian views or popular opinion, which is one of the very outcomes that section 2(b) is intended to protect against: "[T]he guarantee of freedom of expression serves to protect the right of the minority to express its view, however unpopular it may be; adapted to this context, it serves to preclude the majority's perception of 'truth' or 'public interest' from smothering the minority's perception. The view of the majority has no need of constitutional protection; it is tolerated in any event." ${ }^{2}$ Though this type of reasoning may ultimately be the byproduct of a purposive approach to the Charter, constitutional decision-making should still be grounded in principled and logical legal reasoning if it is to mean anything to the people affected by those decisions.

\section{Notes}

* B.A. (Hons.) (Alberta), M.A. (Carleton), LL.B. (Ottawa), LL.M. (Osgoode Hall) (expected June 2011). Ranjan Agarwal is an associate in the litigation department at Bennett Jones LLP in Toronto. He was called to the Bar of Ontario in 2004. Rahool Agarwal, Ken Dickerson and Richard Haigh provided comments on an earlier version of this article.

12009 CHRT 26 [Warman]. The Canadian Human Rights Commission has applied to the Federal Court for judicial review of the Tribunal's decision.

2 RSC 1985, c H-6 [CHRA].

3 Canadian Charter of Rights and Freedoms, Part I of the Constitution Act, 1982, being Schedule B to the Canada Act 1982 (UK), 1982, c 11 [Charter]. Canada (Human Rights Commission) v Taylor, 1990 CanLII 26 (SCC), [1990] 3 SCR 892 [Taylor]. See Warman v Kyburz, 2003 CHRT 18, 46 CHRR 425 (CanLII); Warman v Kulbashian, 2006 CHRT 11, 56 CHRR 340 (CanLII); Warman $v$ Winnicki, 2006 CHRT 20, 56 CHRR 381 (CanLII); Warman v Harrison, 2006 CHRT 30, 58 CHRR 414 (CanLII) [Harrison]; Warman v Kouba, 2006 CHRT 50 (CanLII); Warman v Western Canada for US, 2006 CHRT 52 (CanLII); Warman v Tremaine, 2007 CHRT 2, 59 CHRR 391 (CanLII); Warman v Wilkinson, 2007 CHRT 27 (CanLII); Warman v Beaumont, 2007 CHRT 49, 62 CHRR 261 (CanLII).

6 Jonathan Kay, "How to turn a Neo-Nazi into a free-speech martyr" National Post (25 March 2008), online: National Post <http://www.nationalpost.com/story.html?id=327a3a0f-3031-4ae39deb-ela2e12c2ac1\&k=97808>.

$7 \quad$ Warman, supra note 1 at para 11.

$8 \quad$ Ibid at para 12.

9 Harrison, supra note 5.

10 Warman, supra note 1 at paras 20, 30, 50, 62, 79-138, 145.

11 RSC 1960, c 44.

12 Warman, supra note 1 at paras 3-4, 305.

13 Ibid at paras 57, 212.

$14 \quad$ Ibid at para 279.

15 Ibid at para 296.

16 Ibid at para 303.

17 Some of the provincial human rights statutes also prohibit hate speech: Human Rights, Citizenship and Multiculturalism Act, RSA 2000, c H-14, s 3(1)(b); Human Rights Code, RSBC 1996, c 210, s 7(1)(b); Saskatchewan Human Rights Code, SS 1979, c S-24.1, s 14(1)(b); Human Rights Act, SNWT 2002, c 18, s 13(1)(c).

18 CHRA, supra note 2, s 13.

19 SC 2001, c 41, s 88.

20 Jane Bailey, "Private Regulation and Public Policy: Toward Effective Restriction of Internet Hate Propaganda" (2003) 49 McGill Law Journal 59 at 67.

21 CHRA, supra note 2, ss 53(3), 54(1)-(1.1).

22 An Act to amend the Canada Evidence Act and the Criminal Code in respect of persons with disabilities, to amend the Canadian Human Rights Act in respect of persons with disabilities and other matters and to make consequential amendments to other Acts, SC 1998, c 9, s 28.

23 Charter, supra note 3, s 2(b).

242005 SCC 62, [2005] 3 SCR 141 (CanLII).

25 Ibid at para 56 [emphasis in original]. 


\section{Government Is Undermining Democracy in the} Name of Human Rights (Toronto: McClelland \& Stewart, 2009); Joseph Brean, "Hate speech law unconstitutional: rights tribunal" National Post (2 September 2009), online: National Post <http://www.nationalpost.com/news/story. html?id=1954734>; Jesse McLean, "Hate-speech law rejected in rights ruling" Toronto Star (3 September 2009), online: thestar.com <http:// www.thestar.com/article/690252>; Susan Krashinsky, "Hate-speech law violates Charter rights, tribunal rules" Globe and Mail (2 September 2009), online: The Globe and Mail <http:// www.theglobeandmail.com/news/national/hatespeech-law-violates-charter-rights-tribunal-rules/ article1273956/>.

Rainer Knopff \& FL Morton, Charter Politics (Toronto: Nelson Canada, 1992); Paul Weiler, “Two Models of Judicial Decision-Making” (1968) 46 Canadian Bar Review 406 [Weiler].
$57 \quad$ R v Big M Drug Mart, 1985 CanLII 69 (SCC), [1985] 1 SCR 295 (CanLII)at para 116. See also Jonathan L Black-Branch, "Constitutional Adjudication in Canada: Purposive or Political?" (2000) 21:3 Statute Law Review 163 at 165-166.

58 See e.g. Weiler, supra note 55; Elena Kagan, The Development and Erosion of the American Exclusionary Rule: A Study in Judicial Method (M. Phil. Thesis, Oxford University, 1983) [unpublished].

59 See generally Ankur Bhatt, "Warman v. Lemire: The Constitutionality of Hate Speech Legislation" The Court (22 September 2009), online: The Court <http://www.thecourt.ca/2009/09/22/ warman-v-lemire-the-constitutionality-of-hatespeech-legislation/>.

60 Warman, supra note 1 at para 262.

61 Taylor, supra note 4 at 926-39.

62 Ibid at 933.

631995 CanLII 59 (SCC), [1995] 2 SCR 1130.

64 Kevin Steel, "Drawing the Line" Western Standard (27 February 2006) 15, online: WesternStandard.ca: <http://www.westernstandard.ca/ website/article.php?id=1473>.

65 See e.g. "Writers call for probe into human rights commission” CBC News (6 October 2009), online: CBC News <http://www.cbc.ca/news/canada/story/2009/10/05/human-rights-commission. html>.

66 House of Commons, Notice Paper, 39 $9^{\text {th }}$ Parl, $2^{\text {nd }}$ sess, No 41 (31 January 2008), M-446 (Keith Martin).

67 House of Commons, Standing Committee on Justice and Human Rights, Review of the Canadian Human Rights Act (Section 13), 40 ${ }^{\text {th }}$ Parl, $2^{\text {nd }}$ sess (Ed Fast, Chair).

68 Canadian Human Rights Commission, Report to the Canadian Human Rights Commission Concerning Section 13 of the Canadian Human Rights Act and the Regulation of Hate Speech on the Internet by Richard Moon (Ottawa: Canadian Human Rights Commission, 2008) at 1 [Moon Report].

69 RSC 1985, c C-46.

70 Moon Report, supra note 68 at 31.

711992 CanLII 75 (SCC), [1992] 2 SCR 731 at 732.

72 Ibid at 753. 